\title{
European Society for Ultrasound in Medicine and Biology (EFSUMB) og World Federation of ultrasound in Medicine and Biology (WFUMB)
}

Som medlem i NFUD er man også medlem i EFSUMB og i WFUMB. NFUD betaler i hvert år 8 Euro i kontingent per norsk medlem til EFSUMB i tillegg til utgiftene til abonnement og forsendelse av European Journal of Ultrasound/Ultraschall in der Medizin. En hovedoppgave for EFSUMB er å drive opplæring i bruk av ultralyd innenfor alle medisinske fagmiljø. Det arrangeres hvert år flere "EUROSON schools» som er viderekomne kurs i utvalgte ultralydemner. Man kan f. eks. delta i kurs i kontrastforsterket ultralyd i Hannover eller i ultralydveiledet intervensjon i København.

Dersom man ønsker å få oversikt over kurstilbudene til EFSUMB, kan man besøke hjemmesiden http://www.efsumb.org/intro/home.asp. Her vil man og få full elektronisk tilgang til den mest oppdaterte utgave av «EFSUMB course book», som nå også kommer i en noe forkortet studentutgave. I tillegg er det linker til alle ultralydguidelines og man kan se den populære «case of the month».

I EFSUMBs styret sitter nå Odd Helge Gilja som påtroppende president. Han vil ta fatt på oppgaven som leder i EFSUMB ved neste valg som vil finne sted på EUROSON 2015, 6-8. november 2015 i Athen. I tillegg til Odd Helge er Hilde Berner Hammer deltaker i EFSUMBs «educational committee». Denne jobber med utdanningsaktiviteter, og det siste tilskuddet her er at EFSUMB vil legge til rette for hospitering på akkrediterte sentre som kan tilby spesifisert veiledning i ultralydundersøkelser. På denne måten ønsker EFSUMB å bidra til at det finnes både teoretisk og praktiske læringsressurser tilgjengelig for alle medlemmer og andre ultralydinteresse.

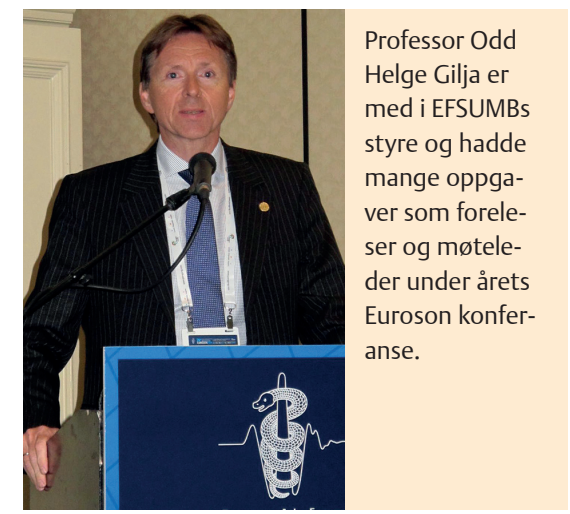

